\title{
Operation Model Summary and Trend Research of the Highway Freight Logistics Park in China
}

\author{
Weijuan Wen, Yue Wu \\ Beijing Wuzi University, Beijing, China \\ Email: newmoon168@126.com
}

How to cite this paper: Wen, W.J. and Wu, Y. (2017) Operation Model Summary and Trend Research of the Highway Freight Logistics Park in China. Modern Economy, 8, 745-752.

https://doi.org/10.4236/me.2017.85052

Received: December 20, 2016

Accepted: May 20, 2017

Published: May 23, 2017

Copyright $\odot 2017$ by authors and Scientific Research Publishing Inc. This work is licensed under the Creative Commons Attribution International License (CC BY 4.0).

http://creativecommons.org/licenses/by/4.0/

\begin{abstract}
Road transportation accounts for $80 \%$ of the market in China, and it is important to research development for the road hub Logistics Park. In this paper, through the analysis of the concept and the main characteristics of Highway Freight Logistics Park, based on the analysis and summary typical operation mode of Highway Freight Logistics Park, combining with the operating environment and development needs to obtain the development trend of operation mode of the Highway Freight Logistics Parkin China.
\end{abstract}

\section{Keywords}

The Highway Freight Logistics Park, Characteristic Analysis of Operation Mode, Development Trend

\section{The Concept of Highway Freight Logistics Park}

According to the State Administration of Quality Supervision Inspection and quarantine China National Standardization Management Committee issued the "classification and fundamental requirements of logistics in the logistics park" standard is defined as: it is the spatial logistics industry agglomeration aggregated by a variety different types of logistics facilities and logistics enterprises that has a certain scale and integrated logistics services, and also is a industry intensive economic function area riled on the relevant facilities in order to reduce the cost of logistics and improve service efficiency. According to the function of logistics park, the logistics park can be divided into: Production Logistics Park, Commerce Distribution Logistics Park, Highway Freight Logistics Park and Integrated Logistics Park [1].

The traffic hub is also known as the transport hub, is comprehensive facilities system formed with transportation mode or transportation line intersection, that has the functions of handling, storage, transit, development, transport, informa- 
tion services and others [2] including highway hub, railway hub, port hub, aviation hub and complex forms. As the highway is the most important form accounted for $80 \%$ of the proportion, so this paper is mainly for highway type research.

According to the conceptual definition of the traffic hub and the logistics park, the definition of the Highway Freight Logistics Park can be defined as follows: it is the area of freight or logistics node agglomeration that relies on making the numerous logistics enterprises together, and bases on gathering logistics resources to provide one-stop service, for the goal to improve the matching efficiency of vehicle cargo information, and reduce logistics costs, with the network as the carrier, to enhance the efficiency of the supply chain for the direction of the development platform of the logistics enterprise cluster and integrated logistics facilities to integrate. In reality, the Highway Freight Logistics Park should meet the following requirements: Have a certain amount of space to achieve the road transport function of the main set of distribution and information service platform.

\section{Main Characteristics of Operation for Highway Freight Logistics Park}

The Highway Freight Logistics Park is especially important in the transportation of goods. It can improve the level of intensive degree and organization in logistics, promote the logistics development in scale and reduce the waste of cargo and reduce traffic congestion. At present, the development of China's traffic hub's logistics park mainly presents the following characteristics:

\subsection{Most of the Park Primarily Devoted to Platform, Does Not Participate in Operations}

The Highway Freight logistics park consists of two parts: One is the owner, he provides the parking lot, warehouse, transportation channel, office space and information trading center and other places and to regulate the operation of public park environment. He belongs to the platform and is not involved in the logistic operation generally, the logistics function mainly rely on enterprises settled. Another is settled enterprises, they access to vehicle or cargo information by the park platform, mainly for freight services.

\subsection{The Park More Focus on Long Distance Transportation than City Distribution [3]}

Logistics park is the logistics node connecting the long-distance transportation or long-distance transportation and city distribution service, built in the traffic arteries and junction area, in order to be able to play the advantages of regional transport of goods collect and distribution, form the inflow and outward radiation of the powerful. But Pay more attention to long distance transportation than city distribution, Logistics enterprises in the park are also more concerned with long-distance transportation. City distribution service capacity is 
weak.

\subsection{Rent Is the Main Revenue Source, Lack of Business Income}

The main revenue of logistics park including source: warehouse rent, equipment rental, management fees, value-added services fees, property management fees, the state and local fiscal funds, tax incentives, the enterprise's profit, land after the appreciation of land rental or sale (land value-added returns) and other. Due to the park owners and enterprises relationship is alliance relationship generally and the Park owner do not participate in operation. So in the current the rent and management fee are the main revenue sources, lack of business income with complementary services to the park enterprises.

\section{Summay on Characteristics of Existing Operation Modes of Highway Freight Logistics Park}

\subsection{Integrated Loose Platform Mode-Transfar Logistics}

1) Introduction of Transfar mode [4]

Transfar Logisticsis a leading domestic Highway Logistics Parkplat form operators, is committed to build China Highway Logistics network operating system, which is based on the organized, informationization, normalized and logistics resources agglomeration, Through the entity Park and information platform for logistics enterprises to provide comprehensive logistics and ancillary services (Figure 1).

2) Transfar profit model [5]

(1) warehouse rental, (2) office rental, (3) parking fees, (4) member management fees, (5) online integrated resource platform services, (6) information technology services. In addition to the above profit, Transfar also provideslogistics consulting, project planning, logistics, financial, exhibition, training and other derivative services.

3) Transfar Logistics characteristics [6]

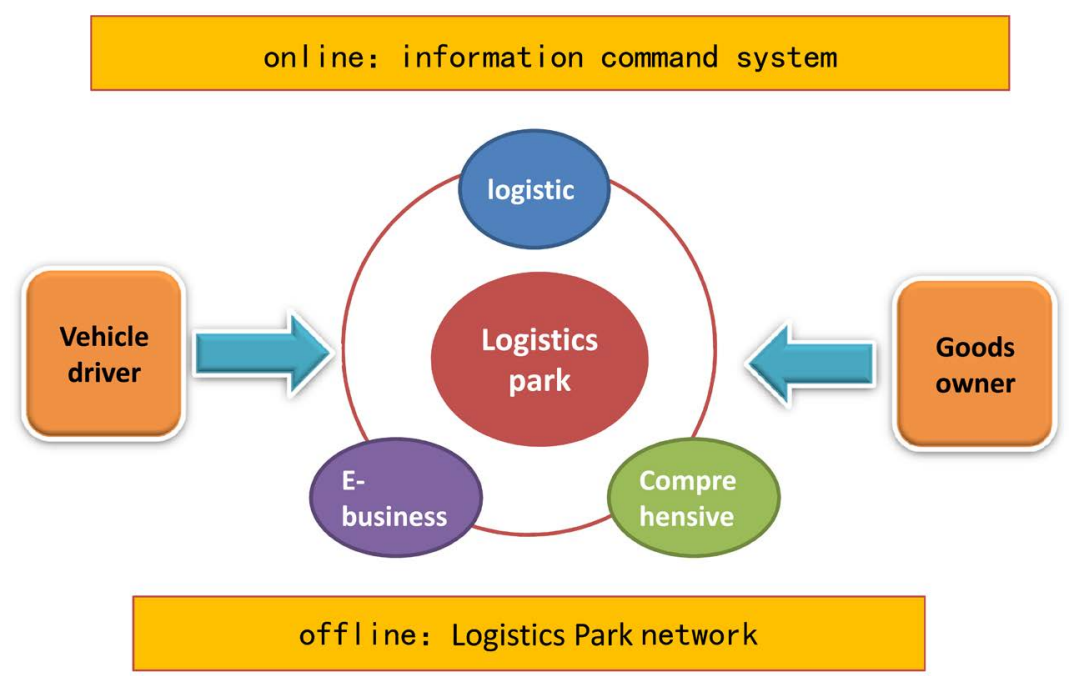

Figure 1. Transfar logistics operation mode. 
As a comprehensive loose type management operation mode, Transfar logistics is the fourth party platform. Transfar logistics park is equivalent to a market, which is to give the freight for the subject freedom platform and providing the site and information for truck drivers and freight enterprise. Usually, general management is run by the freight companies themselves, Transfar only play the role of supervision and execution. In addition to these operations center and information center.

\subsection{Affiliate Management Platform Model-KXTX Company}

1) Introduction of KXTX model [7]

KXTX is a network platform type company, which is committed to driving the high quality micro logisticsenterprises together. KTXT built highway hub parks in the national regional. So that, the small and scattered provinces enterprises and distribution enterprise gathered within the park. Each park circuit can reach capital and major cities in China. In addition to the high quality special line within the park, the outside of park also has join network and the high quality special line members. Through the connection between nodes, KTXT has its own ground network which is covered all the first-tier cities and second-tier cities. Thus, KTXT formed a logistics transportation network across the country (Figure 2).

At the same time, KXTX provides a unified intelligent information system for all the members to realize the whole transportation service visualization, and requires a unified settlement, and ultimately form a set of settlement, finance, monitoring and other functions as one of the operational service system.

2) KXTX profit model [8]

KXTX current revenue mainly comes from rental and software system use fees. It account for around $80 \%$ of the total profits. Management fee Meanwhile, KXTX system customer must open the uniform settlement account when uses intelligent management system. This will gather a lot of money to precipitate in the platform system. Thay canget better development and investment returns through certain means of financial interest and financial benefits which is use this money to continue to expand itself.

3) KXTX characteristics [9]

KXTX is the fourth party platform operation mode. Logistics park and the network use joint venture form. They are both use unified image which together

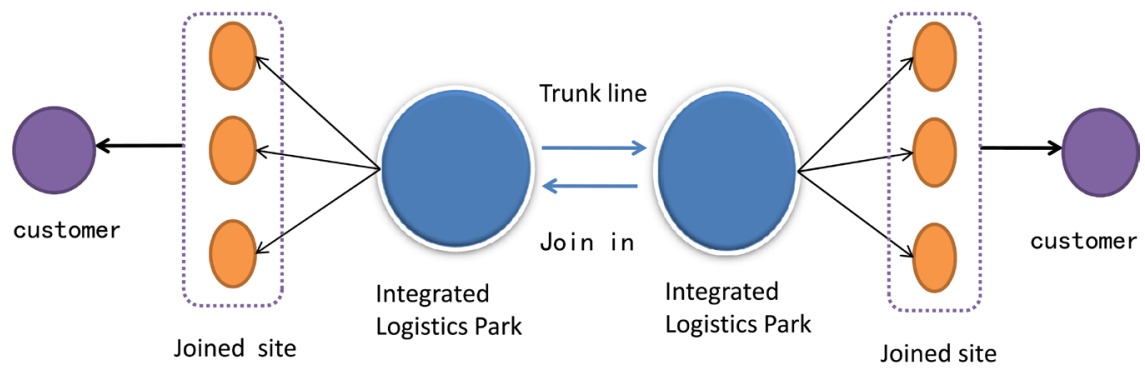

Figure 2. KTXT logistics process and pattern. 
form KXTX logistics network. The freight enterprise in platform is also use joint venture form. The transportation of league is responsible for their own and freedom to choose delivery. But, these freight companies need to use unified image and the same settlement in the platform of KXTX. Therefore, KXTX compared with Transfar, the main profit source are fixed management fees according to the proportion of freight charge and settlement with precipitation besides the cost of rent and software system. It opens up new profit space.

\subsection{Unified Operation Platform Mode-ANE Logistics}

1) ANE model is introduced [10]

ANE logistics was founded on June 1, 2010. It is an integrated suppliers that focus on high-end highway less-than-one carload transport channels and distribution network development. ANE Located in express highway Large less-thanone carload market and focus more on Large less-than-one carload market segments to build China largest carload express joint venture network through integrating traditional logistics lines, less-than-one carload express network and information technology platform.

ANE business system has two core, one is the special line, the other is the store.ANE business entity is special line which formed a network. The store is receiving and distribute system of ANE. The two system of ANE use management platform to operation. Each line has a fixed schedule that marks arriving time and delivering place. It is complete commitment to customers. ANE is build provincial center platform over the country, include large freight station, timing bus, the regional secondary distribution center and a large number of outlets. In areas of the province of platform, organization structure including regional secondary distribution center, the timing of business and some small station. Proprietary lines and hub integrate terminal distribution of a wide range of network by the way of joint venture (Figure 3).

2) ANE Logistics profit mode

ANE Logistics profits besides rent also has the line jointing fee, vehicle management fee, ticket fee and other property income.

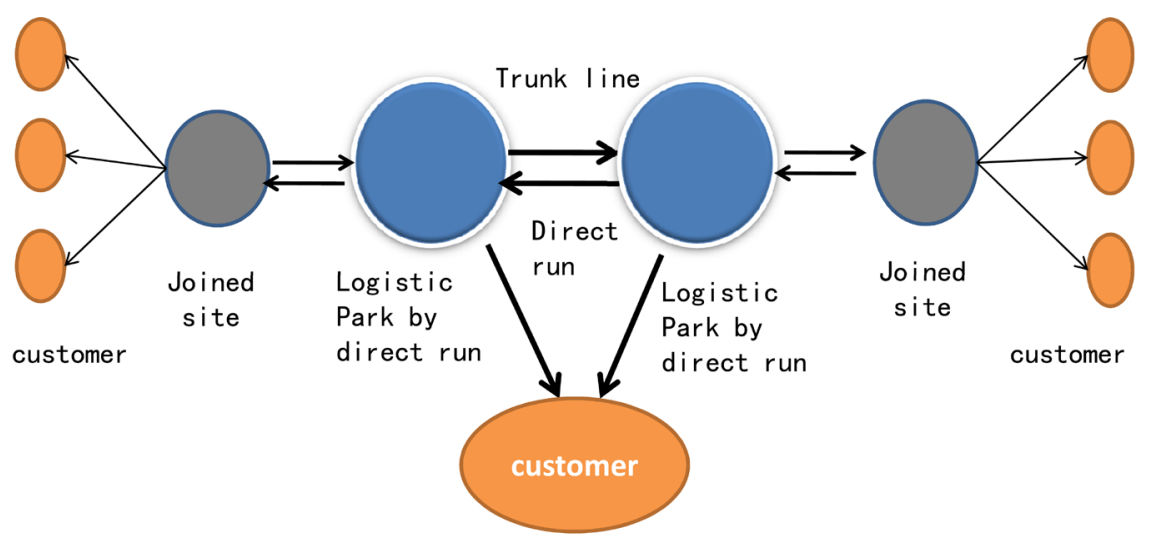

Figure 3. [5] ANE Logistics process and pattern. 
3) ANE Logistics characteristics [11]

ANE Logistics uses unified enterprise platform operation mode. The operation of node and line should to be in accordance with the ANE requirements. That is to say, no matter how many join node and line operators, they only use ANE Logistics image. In particular, ANE is express network model with strict rules and all stores should follow ANE logistics rules. For example, delivery goods must use unified charge, any self-delivery fee is strictly forbidden, otherwise, this will be lead to heavy fines. ANE Logistics take over the original line management from join partners. The cooperation partners can participate in the management and share interests. Every line has a fixed schedule, which marks arriving time and delivering place. It is complete commitment to customers.

\section{Analysis Development Trend of Highway Freight Logistics Park Operation Model}

\subsection{Park Platform Model Become Mature and Coexist with Various at the Some Time}

Internet fully detonate a new change of China logistics in 2014, the logistics platform in hatch, such as transfar logistics, KXTX logistics, and ANE logistics etc. Logistics Park entity and intelligent management system of information platform of base + network model has been more and more accepted by the industry and gradually mature. Although these Freight Logistics Park modes represent different operation modes respectively, such as the comprehensive loose platform mode, joining platform management mode, and Unified operation platform management mode. These Highway Freight Logistics Parks have good function of integrate the platform, although they have different operation characteristics. They play a good role that to concentration and optimize resources for small, scattered and weak part in China and solve the problems of transportation resources scattered, lack of scale effect, market chaos and disorderly competition. At present, although logistics resource integration platform in different operating mode, but all of them complied with China current owner intensive enterprise services, integrated freight organization and government requirements. They fit the current development environment and requirements of Chinese logistics market. China has a large logistics market and with a wide range of resources. An enterprise cannot monopolizes all. Thus, each enterprise choose different model according to their own conditions. As a result, these patterns will be foreseeable co-exist at the same time.

\subsection{Logistics Park Will Pay More Attention to the End Resource Integration and the New Pattern Will Be Created}

With the development of China transportation market and Logistics Park, China highway transportation has been fully developed and got resources integration. China arterial road transportation has a good service ability, but from the perspective of the whole chain of transport, at the end of transport of receiving and distribution has not keep up with the construction time. So that, the last kilome- 
ter efficiency is low and the cost is higher. As urban congestion is more serious in the future as well as the big traffic pressure, predictably, unified the model of integrated city distribution (receiving) and long-distance transport is a Highway Freight Logistics Park development trend (Figure 4).

Specific features include:

1) Have the function of integrating logistics companies, providing space and platform same as the general Freight Logistics Park;

2) Have function of unified goods collection, to provide the door receiving for city enterprises and wholesale markets. Complete the Long-distance transportation by choose logistics enterprises inside or outside of park through the intelligent information system as well as unified settlement.

3) With a joint distribution function, it provides joint distribution function in view of the Long-distance transportation goods from inside or outside of park. It will help the freight enterprises of park to realize the last kilometer of urban distribution. It also will charge service fee.

As a result, in addition to the above several fees, such as rents, join fees, system fees and unification settlement fund precipitation. This profit model also includes the city unified goods collection and distribution fees and brand value due to attract demand of growing business.

\section{Summary}

The Highway Freight Logistics Park is the node or logistics platform that has the function of collection, distribution and information service. The core is the truck and goods information matching and logistics services. It plays an important role in China's Logistics Park. The first part of this paper is based on the introduction concept of Logistics Park and transportation hub to define the concept of the Highway Freight Logistics Park. The second part analyzes and summarizes three main operation characteristics of the Highway Freight Logistics Park. The third part summarizes three kinds of operating modes and names them, i.e. loose platform mode, management platform mode and joining the unified operation platform model, meanwhile it selects the corresponding representative enterprises-Transfar Logistics, KXTX company, and ANE Logistics to analyze and elaborate. The fourth part proposes the development trend of logistics park mode of the Highway Freight Logistics Park based on analysis Chinese logistics development environment and the trend of the development, that is the

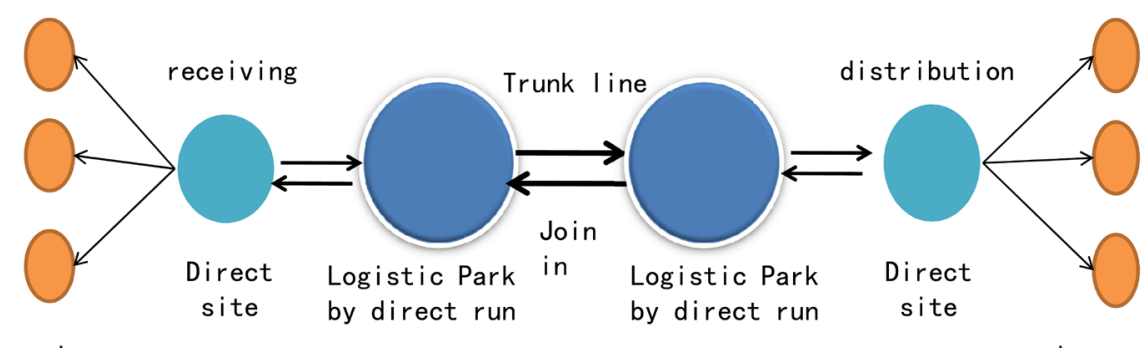

customer

customer

Figure 4. The new logistics park process and pattern. 
coexistence of a variety of modes in the short term, and will appear a new mode which be pay more attention to the terminal distribution. This paper, on the basis of summing and analyzing the operating characteristics, creatively summed up three modes and put forward two development trends, these ideas and content all for the rich the Logistics Park theory, and provided a theoretical guidance for the development of Highway Freight Logistics Park.

\section{Fund}

The paper is supported by Beijing Social Science Key Project "Research on the reconstruction of Beijing logistics system under the background of non capital function" (No. 16JDGLA016).

\section{References}

[1] General Administration of Quality Supervision, Inspection and Quarantine of the People's Republic of China (AQSIQ), Standardization Administration of the People's Republic of China (2008) Classification and Basic Requirements of Logistics Park (GB/T21334-2008). China Standard Press, Beijing.

[2] General Administration of Quality Supervision, Inspection and Quarantine of the People's Republic of China (AQSIQ), Standardization Administration of the People's Republic of China (2007) Logistics Park Service Specifications and Evaluation Indicators (GB/T 30334-2013). China Standard Press, Beijing.

[3] China Federation of Logistics and Purchasing Committee (2015) Logistics Park Operation Statistical Analysis Report.

http://csl.chinawuliu.com.cn/html/19888327.html

[4] Transfar Logistics Introduction. http://www.transfar56.com/

[5] Interpretation of Domestic Famous Logistics Park Mode. http://cache.baiducontent.com/c?m

[6] Yan, Q. (2014) The Research Based on Transfar Logistics Port of Highway Service Mode. Min Ying Ke Ji, No. 8.

[7] KXTX Introduction. http://www.kxtx.cn/

[8] China's Top Ten Logistics Platform Mode in 2014. http://www.56lem.com/news/show-1104.html

[9] ANE Logistics Robust Way of Business-An Interview with Yong Jun Wang, Chairman of ANE Logistics. http://www.materialflow.com.cn/article.do?command

[10] Chen, J.W. Logistics Industry Platform-KXTX Logistics Mode. http://www.kxtx.cn/NewsDetail.aspx

[11] The Difference between KXTX and ANE. Logistics. https://www.zhihu.com/ 
Submit or recommend next manuscript to SCIRP and we will provide best service for you:

Accepting pre-submission inquiries through Email, Facebook, LinkedIn, Twitter, etc. A wide selection of journals (inclusive of 9 subjects, more than 200 journals)

Providing 24-hour high-quality service

User-friendly online submission system

Fair and swift peer-review system

Efficient typesetting and proofreading procedure

Display of the result of downloads and visits, as well as the number of cited articles Maximum dissemination of your research work

Submit your manuscript at: http://papersubmission.scirp.org/

Or contact me@scirp.org 